\title{
Effects of mannan-oligosaccharides' supplementation on hatching characteristics of four close-bred flocks of Japanese quail breeders
}

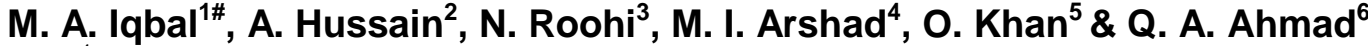 \\ ${ }^{1}$ Department of Zoology, Women University of Azad Jammu \& Kashmir, Bagh, Pakistan \\ ${ }^{2}$ Department of Wildlife \& Ecology, University of Veterinary \& Animal Sciences, Lahore, Pakistan \\ ${ }^{3}$ Department of Zoology, University of the Punjab, Lahore, Pakistan \\ ${ }^{4}$ Department of Forestry, Range \& Wildlife, Ghazi University, Dera Ghazi Khan, Pakistan \\ ${ }^{5}$ Departments of Zoology, Virtual University of Pakistan \\ ${ }^{6}$ Department of Zoology, Government College University, Faisalabad, Pakistan
}

(Received 18 March 2017; Accepted 4 June 2017; First published online 6 September 2017)

\begin{abstract}
Copyright resides with the authors in terms of the Creative Commons Attribution 4.0 South African License.
See: http://creativecommons.org/licenses/by/4.0/za

Condition of use: The user may copy, distribute, transmit and adapt the work, but must recognize the authors and the South African Journal of Animal Science.
\end{abstract}

\begin{abstract}
The present study was conducted to evaluate the effects of mannan-oligosaccharides' (MOS) supplementation on hatching characteristics of four close-bred flocks (CBFs) of Japanese quail (Coturnix coturnix japonica) breeders. A total of 960 Japanese quail breeders, aged 12 weeks old, were randomly selected and divided into four groups $(n=240)$ with twelve replicates $(n=20)$ in a completely randomized design (15 $\delta: 5$ ). The birds were a fed corn-based basal diet (group D) or basal diet supplemented with MOS at the levels of $0.25 \%$ (group A), $0.5 \%$ (group B) and $1.0 \%$ (group C) for 15 weeks. The collected data were analyzed by two-way ANOVA techniques using Statistical Analysis System. The fertility and hatchability of $0.50 \%$ MOS-supplemented group was significantly higher than other treatment groups. Similarly, fertility and hatchability percent of fertile eggs of Kaleem flock was significantly higher than other flocks, while dead in-shells were significantly lower in Sadat flock. Conclusively, MOS supplementation positively influences the fertility and hatchability of quail breeders.
\end{abstract}

Keywords: Fertility, hatchability, Japanese quail breeders, mannan-oligosaccharides, poultry biotechnology

\#Corresponding author: anwariqbalk@yahoo.com

\section{Introduction}

The application of antibiotic growth promoters (AGPs) in animal feeds has been banned by the European Union in 2006, as it caused side effects like antibiotic resistance and drug residues in meat (Verdonk et al., 2005). Scientists and researchers are trying to find a safe and effective alternative of AGPs. Prebiotics, probiotics and symbiotics are considered to be useful alternatives to AGPs in animal nutrition (Shashidhara \& Dewegowda, 2003). Prebiotics are food constituents that are not assimilated by host enzymes and influence host performance by increasing the development of some useful microbes of the gut (Gibson et al., 2004). They are the source of energy for the beneficial bacterial flora inhabiting the intestine like Lactobacilli and Bifidobacteria spp. (Dankowiakowska et al., 2013). They also induce enhancement of beneficial bacterial populations of the gut by reducing pathogenic bacterial loads (Clostridium perfringens, Salmonella and Escherichia coli) (Lopes et al., 2013; Samanta et al., 2013; de Paiva et al., 2015).

Mannan-oligosaccharides (MOS) are important prebiotics, which are being used as an alternative to AGPs in animal diets (Roberfroid 2007; Dankowiakowska et al., 2013). They are natural components of the outer cell wall of various species of yeast, made up of mannose units and extracted from the cell wall of Saccharomyces cerevisiae (Spring et al., 2000). The commercially available product Bio-MOS® (Alltech, Inc., Nicholasville, KY, USA) is a source of MOS and was introduced in 1993 as a feed additive for broiler chickens (Hooge, 2003). Generally it is considered that MOS modify intestinal microflora, promote health of GIT, increase digestion and absorption of nutrients and thus stimulate the immune system (Halas \& Nochta, 2012). The MOS are not hydrolyzed by the host enzymes and fermented by intestinal microbiota (Lomax \& Calder, 2009). These provide competitive binding sites for pathogens with mannose-specific type- 1 fimbriae such as Salmonella and E. coli and decrease their attachment to intestinal wall and ultimately they are excreted from the gut. The MOS supplementation constantly increases the intestinal populations of beneficial Lactobacillus and Bifidobacterium spp (Yang et al., 2008). Due to these benificial changes in microflora, the 
number of goblet cells and length of intestinal villi increases, and these promote health and function of the host gut (Rehman et al., 2009; Bonos et al., 2010; Vahdatpour et al., 2011).

The MOS supplementation in feed has been shown to have a positive influence on fertility and hatchability of Japanese quail breeders (Güçlü, 2011; Abd El-Samee et al., 2012). However, limited data are available on these phenomena. Therefore, this study was designed to evaluate the influence of MOS supplementation on fertility and hatchability of four close-bred flocks (CBFs) of Japanese quail breeders and to sort out the most feasible strain of quail in terms of better reproduction performance in Pakistan.

\section{Materials and Methods}

A total of 960, 12-week old Japanese quail breeders, of four CBFs namely, Major, Kaleem, Sadat and Zahid, were selected for experiment at Avian Research and Training (ART) Center, University of Veterinary and Animal Sciences, Lahore, Pakistan. Each strain-group was comprised of 240 birds and divided into four treatment groups $(n=60)$ named as $A, B, C$, and $D$, and then further replicated into three groups $(n=20)$ in a completely randomized design (CRD) (15 female +5 male) according to pattern (4 strains $x 4$ treatment groups $\times 3$ replicates).

The birds were housed in French-made multi-deck cages. Each compartment of cage provided separate feeding, drinking, breeding, and egg collection space to birds. The lighting programme of $16 \mathrm{~L}: 8 \mathrm{D}$ was adopted for a 15-week trial. The birds were fed a corn-based basal diet prepared by Hi-Tech feed industries (Pvt.), Lahore, Pakistan, following NRC (1994) principles containing $2900 \mathrm{kcal} / \mathrm{kg}$ metabolizable energy (M.E), $20 \%$ crude protein (C.P), $3 \%$ calcium (Ca) and $0.4 \%$ phosphorus (Table 1) or the same basal diet supplemented with different levels of MOS. Birds of groups A, B, and C were given basal diet with addition of $0.25 \%, 0.5 \%$ and $1.0 \%$ MOS, respectively, while birds of group D were fed basal diet only and considered as control group. Water was provided through nipple drinkers and feed through trough feeders. Feed was added in feeders twice a day, in the morning and evening. Birds were fed quail breeder ration and had access to drinking water ad libitum throughout the experimental period.

Table 1 Ingredients and chemical composition of experimental basal diet

\begin{tabular}{lccc}
\hline Ingredient & $\%$ & Nutrient & \\
\hline Maize & 30.0 & ME Kcal/kg & 2900 \\
Rice polish & 8.00 & $\mathrm{CP}$ & $20.00 \%$ \\
Canola meal & 10.0 & $\mathrm{Ca}$ & $3.00 \%$ \\
Soybean meal & 25.0 & Available P & $0.40 \%$ \\
Corn gluten $60 \%$ & 5.00 & Phytate P & $0.34 \%$ \\
Rice tips & 14.0 & Total P & $0.74 \%$ \\
Lime stone & 1.00 & Crude fibre & $4.38 \%$ \\
D-L Methionine & 0.10 & Linoleic acid & $1.00 \%$ \\
L-Lysine & 0.20 & Methionine & $0.50 \%$ \\
Threonine & 0.15 & Lysine & $1.30 \%$ \\
Soy oil & 1.85 & & \\
DCP & 1.50 & & \\
Vitamin premix & 0.20 & & \\
Molasses & 3.00 & & \\
Total & 100 & & \\
& & & \\
\hline \multicolumn{1}{c}{} & & & \\
\hline
\end{tabular}

ME: metabolizable energy; CP: crude protein

About 25 eggs from each replicate (total 1200) were collected randomly, weighed and kept in an Italian made (Victoria) incubator for hatching. After the completion of hatching, chicks were counted, weighed and their hatchability percentage was calculated following Anandh et al., (2012) and Dauda et al., (2014) using following formulae: 


$$
\begin{gathered}
\text { Fertility Rate } \%=\frac{\text { No. of Fertilized eggs }}{\text { Total no. of egg set }} \times 100 \\
\text { Hatchability } \%=\frac{\text { No. of hatched chicks }}{\text { Total no. of egg set }} \times 100 \\
\text { Hatchability of fertile eggs } \%=\frac{\text { No. of hatched chicks }}{\text { No. of fertilized egg set }} \times 100
\end{gathered}
$$

Un-hatched eggs were broken to analyze the dead germs, dead in-shells, infertile eggs and their percentage was calculated using the following formulas:

$$
\begin{gathered}
\text { Dead germ } \%=\frac{\text { No. of dead germs }}{\text { No. of egg set }} \times 100 \\
\text { Dead inshell } \%=\frac{\text { No. of dead in }- \text { shells }}{\text { No. of eggs set }} \times 100 \\
\text { Infertile egg } \%=\frac{\text { No. of Infertile eggs }}{\text { No. of eggs set }} \times 100
\end{gathered}
$$

The experimental data were analyzed by applying Completely Randomized Design (CRD) under factorial arrangement using General Linear Model (GLM) procedures. Means were separated using Duncan's Multiple Range (DMR) (Duncan, 1955) test with the help of SAS (SAS, 2002-03).

\section{Results}

The effects of MOS supplementation on hatching traits (dead germ percent, dead in-shell percent, infertile egg percent and hatchability percent in four CBFs of Japanese quail breeders (Major, Kaleem, Sadat, Zahid) recorded during the study are presented in Tables 2 \& 3 . Our results indicated that dead germ percent was not affected by MOS supplementation in treatment groups, CBFs and in interactions between CBFs and MOS levels. The lowest dead germ percent was recorded in group B; however, it did not differ significantly $(P<0.05)$ among other feeding groups (Table 2). No significant differences were noted among dead in-shells in MOS-supplemented and control groups; however, it vary significantly among CBFs. Dead in-shells were lower in MOS-supplemented groups than in control group and among CBFs, the lowest dead in-shells were recorded in Sadat flock and the highest in Kaleem flock. Furthermore, no changes were observed among interactions between CBFs and MOS levels (Table 2).

In the current study, significant differences in infertile egg percent were recorded in MOSsupplemented and control groups. The lowest infertility was recorded in birds fed with $0.50 \% \mathrm{MOS}-$ supplemented diet and the highest infertility was recorded in control group. Among CBFs, percentage of infertile eggs of Kaleem flock was significantly lower than other flocks; however, the highest infertility was recorded in Sadat flock. Significant differences were recorded in interactions between CBFs and MOS levels. The lowest infertile egg percent was found in B group of Kaleem flock and the highest in A group of Sadat flock (Table 2).

Hatchability percent of total eggs set was different significantly in MOS-supplemented groups as compared to control. The highest hatchability percent of total eggs set was recorded in birds fed with $0.50 \%$ MOS-supplemented diet compared to all other groups and the lowest was recorded in control group. Nonsignificant changes were recorded in hatchability percent of total eggs set among CBFs. Significant differences were recorded in interactions between CBFs and MOS levels. Hatchability percent of total eggs set was significantly higher in group B of Zahid flock and the lowest in the control group of the same flock (Table 3). 
Table 2 Dead germs, dead in-shells and infertile eggs percent (Mean \pm SEM) of quail parent flocks fed with different levels of MOS

\begin{tabular}{|c|c|c|c|c|}
\hline \multirow{2}{*}{ CBFs } & \multirow{2}{*}{$\begin{array}{c}\text { MOS level } \\
(\%)\end{array}$} & \multicolumn{3}{|c|}{ Parameters } \\
\hline & & Dead germ (\%) & Dead in-shells (\%) & Infertile egg (\%) \\
\hline Major & & $4.25 \pm 0.51$ & $4.58^{\mathrm{a}, \mathrm{b}} \pm 0.40$ & $16.25^{\mathrm{b}} \pm 0.70$ \\
\hline Kaleem & & $4.75 \pm 0.60$ & $5.25^{\mathrm{a}} \pm 0.51$ & $15.42^{\mathrm{b}} \pm 0.60$ \\
\hline Sadat & & $4.42 \pm 0.58$ & $3.75^{b} \pm 0.48$ & $17.58^{\mathrm{a}} \pm 0.50$ \\
\hline \multirow[t]{5}{*}{ Zahid } & & $3.83 \pm 0.42$ & $4.92^{\mathrm{a}, \mathrm{b}} \pm 0.31$ & $16.42^{\mathrm{a}, \mathrm{b}} \pm 0.69$ \\
\hline & 0.25 & $4.67 \pm 0.38$ & $4.42 \pm 0.40$ & $18.08^{\mathrm{a}} \pm 0.48$ \\
\hline & 0.50 & $3.17 \pm 0.49$ & $4.58 \pm 0.43$ & $14.00^{c} \pm 0.43$ \\
\hline & 1.00 & $4.75 \pm 0.64$ & $4.00 \pm 0.56$ & $16.08^{b} \pm 0.57$ \\
\hline & 0.00 & $4.67 \pm 0.47$ & $5.50 \pm 0.29$ & $17.50^{\mathrm{a}} \pm 0.38$ \\
\hline \multicolumn{5}{|c|}{ CBFs $\times$ MOS level $(\%)$} \\
\hline \multirow[t]{4}{*}{ Major } & 0.25 & $5.67 \pm 0.67$ & $4.33 \pm 0.88$ & $18.33^{\mathrm{a}, \mathrm{b}} \pm 1.20$ \\
\hline & 0.50 & $3.67 \pm 1.20$ & $4.33 \pm 0.88$ & $14.00^{\mathrm{e}, \mathrm{f}} \pm 0.58$ \\
\hline & 1.00 & $3.67 \pm 1.45$ & $4.33 \pm 1.20$ & $15.00^{\mathrm{c}, \mathrm{d}, \mathrm{e}, \mathrm{f}} \pm 1.00$ \\
\hline & 0.00 & $4.00 \pm 0.58$ & $5.33 \pm 0.33$ & $17.67^{\mathrm{a}, \mathrm{b}, \mathrm{c}} \pm 1.20$ \\
\hline \multirow[t]{4}{*}{ Kaleem } & 0.25 & $4.33 \pm 0.33$ & $4.67 \pm 1.20$ & $17.33^{\mathrm{a}, \mathrm{b}, \mathrm{c}, \mathrm{d}} \pm 1.20$ \\
\hline & 0.50 & $3.33 \pm 1.45$ & $4.67 \pm 1.33$ & $13.33^{\dagger} \pm 0.33$ \\
\hline & 1.00 & $6.00 \pm 1.52$ & $5.33 \pm 1.20$ & $14.67^{\mathrm{d}, \mathrm{e}, \mathrm{f}} \pm 1.20$ \\
\hline & 0.00 & $5.33 \pm 1.20$ & $6.33 \pm 0.33$ & $16.33^{\mathrm{a}, \mathrm{b}, \mathrm{c}, \mathrm{d}, \mathrm{e}} \pm 0.33$ \\
\hline \multirow[t]{4}{*}{ Sadat } & 0.25 & $4.67 \pm 1.20$ & $4.00 \pm 0.58$ & $19.00^{\mathrm{a}} \pm 1.15$ \\
\hline & 0.50 & $3.67 \pm 0.88$ & $4.33 \pm 1.20$ & $15.67^{\mathrm{b}, \mathrm{c}, \mathrm{d}, \mathrm{e}, \mathrm{f}} \pm .67$ \\
\hline & 1.00 & $3.67 \pm 1.45$ & $2.00 \pm 0.58$ & $18.33^{\mathrm{a}, \mathrm{b}} \pm 0.67$ \\
\hline & 0.00 & $5.67 \pm 1.20$ & $4.67 \pm 0.88$ & $17.33^{a, b, c, d} \pm 0.33$ \\
\hline \multirow[t]{4}{*}{ Zahid } & 0.25 & $4.00 \pm 0.58$ & $4.67 \pm 0.88$ & $17.67^{\mathrm{a}, \mathrm{b}, \mathrm{c}} \pm 0.33$ \\
\hline & 0.50 & $2.00 \pm 0.00$ & $5.00 \pm 0.00$ & $13.50^{\dagger} \pm 1.00$ \\
\hline & 1.00 & $5.67 \pm 0.33$ & $4.33 \pm 0.88$ & $16.33^{\mathrm{a}, \mathrm{b}, \mathrm{c}, \mathrm{d}, \mathrm{e}} \pm 0.33$ \\
\hline & 0.00 & $3.67 \pm 0.33$ & $5.67 \pm 0.33$ & $18.67^{\mathrm{a}} \pm 0.33$ \\
\hline
\end{tabular}

\footnotetext{
Means within column with different alphabets are different significantly at $P<0.05$. Order of significance is as: $\mathrm{a}>\mathrm{b}>\mathrm{c}>$ d

CBFs: Close-bred flocks; MOS: mannan-oligosaccharides
}

The hatchability percent of fertile eggs was different significantly among MOS-supplemented groups compared to control. The highest hatchability per cent of fertile eggs was recorded in birds fed with $0.50 \%$ MOS-supplemented diet and the lowest in control group. Similarly significant changes were recorded in hatchability percent found in the fertile eggs among CBFs. Hatchability percent of fertile eggs of Kaleem flock was significantly higher than that of other flocks, and the lowest was recorded in the Sadat flock. Significant differences were recorded in the interactions between CBFs and MOS levels. Hatchability percent of fertile eggs was significantly higher in B group of the Zahid flock than in the other groups and the lowest value was recorded in control group of the same flock (Table 3).

\section{Discussion}

Egg weight, egg size and quality, health and nutrition of breeders are the most important factors that affect hatchability and fertility (King'ori, 2011). Results of the present study indicated that MOS supplementation did not significantly affect some hatching characteristics such as dead germs and dead inshells percent in any treatment group. These findings are different from the findings of Shashidhara \& Dewegowda (2003) who reported that MOS supplementation significantly lower dead in-shells percentage. 
Similar findings were reported by Hajati et al. (2014). They described that prebiotics and probiotics supplemented-diets results in reduction in dead in-shells percent of breeders in MOS-supplemented groups than that of control. De Lange et al. (2007) reported significant reduction in percentage of dead in-shells and infertile eggs of Ross broiler stock when fed with MOS-supplemented diet.

Table 3 Hatchability and hatch of fertile (Mean \pm SEM) of quail parent flocks fed with different levels of MOS

\begin{tabular}{|c|c|c|c|}
\hline \multirow{2}{*}{ CBFs } & \multirow{2}{*}{$\begin{array}{l}\text { MOS level } \\
(\%)\end{array}$} & \multicolumn{2}{|c|}{ Parameters } \\
\hline & & Hatchability (\%) & Hatch of fertile (\%) \\
\hline \multicolumn{2}{|l|}{ Major } & $74.92 \pm 0.92$ & $83.75^{\mathrm{a}} \pm 0.70$ \\
\hline \multicolumn{2}{|l|}{ Kaleem } & $74.58 \pm 0.97$ & $84.58^{a} \pm 0.60$ \\
\hline \multicolumn{2}{|l|}{ Sadat } & $74.25 \pm 0.84$ & $82.42^{\mathrm{b}} \pm 0.50$ \\
\hline \multicolumn{2}{|l|}{ Zahid } & $74.83 \pm 1.02$ & $83.58^{a, b} \pm 0.69$ \\
\hline & 0.25 & $72.83^{\mathrm{c}} \pm 0.81$ & $82.92^{c} \pm 0.48$ \\
\hline & 0.50 & $78.25^{\mathrm{a}} \pm 0.49$ & $86.00^{\mathrm{a}} \pm 0.43$ \\
\hline & 1.00 & $75.17^{\mathrm{b}} \pm 0.70$ & $83.92^{\mathrm{b}} \pm 0.75$ \\
\hline & 0.00 & $72.33^{\mathrm{c}} \pm 0.40$ & $82.50^{c} \pm 0.38$ \\
\hline \multicolumn{4}{|c|}{ CBFs $\times$ MOS level (\%) } \\
\hline \multirow[t]{4}{*}{ Major } & 0.25 & $72.67^{f} \pm 1.67$ & $81.67^{\mathrm{e}, \mathrm{f}} \pm 1.20$ \\
\hline & 0.50 & $78.00^{a, b} \pm 0.00$ & $86.00^{a, b} \pm 0.58$ \\
\hline & 1.00 & $77.00^{\mathrm{a}, \mathrm{b}, \mathrm{c}} \pm 0.58$ & $85.00^{\mathrm{a}, \mathrm{b}, \mathrm{c}, \mathrm{d}} \pm 1.00$ \\
\hline & 0.00 & $73.00^{\mathrm{c}, \mathrm{d}, \mathrm{e}, \mathrm{f}} \pm 0.00$ & $82.33^{\mathrm{d}, \mathrm{e}, \mathrm{f}} \pm 1.20$ \\
\hline \multirow[t]{4}{*}{ Kaleem } & 0.25 & $73.67^{\mathrm{c}, \mathrm{d}, \mathrm{e}, \mathrm{f}} \pm .03$ & $82.67^{\mathrm{c}, \mathrm{d}, \mathrm{e}, \mathrm{f}} \pm 1.20$ \\
\hline & 0.50 & $73.33^{\mathrm{a}} \pm 0.33$ & $86.67^{\mathrm{a}} \pm 0.33$ \\
\hline & 1.00 & $74.00^{\mathrm{b}, \mathrm{c}, \mathrm{d}, \mathrm{e}, \mathrm{f}} \pm 0.00$ & $85.33^{a, b, c} \pm 1.20$ \\
\hline & 0.00 & $72.00^{\mathrm{e}, \mathrm{f}} \pm 1.15$ & $83.67^{b, c, d, e, f} \pm 0.33$ \\
\hline \multirow[t]{4}{*}{ Sadat } & 0.25 & $72.33^{\mathrm{d}, \mathrm{e}, \mathrm{f}} \pm 2.19$ & $81.00^{\dagger} \pm 1.15$ \\
\hline & 0.50 & $76.33^{a, b, c, d} \pm 0.88$ & $84.33^{\mathrm{a}, \mathrm{b}, \mathrm{c}, \mathrm{d}, \mathrm{e}} \pm 0.67$ \\
\hline & 1.00 & $76.00^{\mathrm{a}, \mathrm{b}, \mathrm{c}, \mathrm{d}, \mathrm{e}} \pm 1.53$ & $81.67^{e, f} \pm 0.67$ \\
\hline & 0.00 & $72.33^{\mathrm{d}, \mathrm{e}, \mathrm{f}} \pm 0.33$ & $82.67^{\mathrm{c}, \mathrm{d}, \mathrm{e}, \mathrm{f}} \pm 0.33$ \\
\hline \multirow[t]{4}{*}{ Zahid } & 0.25 & $73.67^{\mathrm{c}, \mathrm{d}, \mathrm{e}, \mathrm{f}} \pm 1.20$ & $82.33^{\mathrm{d}, \mathrm{e}, \mathrm{f}} \pm 0.33$ \\
\hline & 0.50 & $80.00^{\mathrm{a}} \pm 1.00$ & $87.00 \pm 1.00^{\mathrm{a}}$ \\
\hline & 1.00 & $73.67 \pm 1.20^{\text {cdef }}$ & $83.67^{\mathrm{b}, \mathrm{c}, \mathrm{d}, \mathrm{e}, \mathrm{f}} \pm 0.33$ \\
\hline & 0.00 & $72.00^{e, f} \pm 0.58$ & $81.33^{\dagger} \pm 0.33$ \\
\hline
\end{tabular}

Means within column with different alphabets are different significantly at $P<0.05$. Order of significance is as: $\mathrm{a}>\mathrm{b}>\mathrm{c}>$ d

CBFs: Close-bred flocks; MOS: mannan-oligosaccharides

Furthermore, the hatchability percentage was increased in the current study with significant reduction in percentage of egg infertility in MOS-supplemented groups than that of control. The lowest infertility was recorded in birds fed with $0.50 \%$ MOS-supplemented diet compared to all other groups and the highest infertility in control group. This reduction in infertile egg percent might be due to the production of healthy eggs with better quality as MOS can enhance nutrients' absorbance necessary for production performance. These findings are consistent with those of Abd El-Samee et al. (2012), who concluded that bioplex zinc alone or in combination with MOS-supplemented diet significantly improve fertility and hatchability of laying quails. Similar findings were documented by Considine (2000) in broilers breeder in Brazilian environment and Shashidhara \& Dewegowda (2003) in Indian conditions, while Güçlü (2011) documented a slight 
increase in egg fertility and hatchability due to dietary supplementation of prebiotics. They further added that dead in-shells and infertile eggs percentage were lowered by MOS supplementation. Kocher (2007) also reported improved laying performance and hatchability in broiler breeders in MOS-fed group than that of control.

Increased fertility and hatchability percentage in this study might be due to fact that MOS supplementation significantly increased semen quality and density of spermatozoa due to improved digestion and absorption of nutrients that ultimately increase hatchability as reported earlier by Shashidhara \& Dewegowda (2003). Other factor involved is reduction of pathogens like $E$. coli in the gut by MOS addition (Spring et al., 2000) and in return, promotes better absorption and utilization of nutrients necessary for quality health of breeders. Strain variation is main factor that affect hatchability and fertility percent in Japanese quails. Fertility varies highly even within same strain due to improper ratio of males, infertile males in the flock and poor management (Malago \& Baitilwake, 2009). In the current study, hatchability percentage of total eggs set did not change significantly; however, the hatchability percentage of fertile eggs, infertile egg percent, and dead in-shells vary significantly in different flocks of Japanese quail breeders. Hatchability percent of fertile eggs and fertility rate of Kaleem flock was significantly better than other flocks, however, the lowest dead in-shells were recorded in Sadat flock. Present results are in accordance with the findings of Rehman \& Qaisrani (2013) and Akram et al. (2014) who reported significant differences in fertility and hatchability among CBFs of laying quails. However, Haidary (2013) reported non-significant differences in fertility and hatchability among different CBFs.

\section{Conclusion}

The addition of MOS in the diet of quail breeders positively influenced the hatching characteristics of Japanese quail breeders. Out of the four flocks, birds of Kaleem flock and among treatment groups, birds feeding $0.50 \%$ MOS-supplemented diet showed the best fertility and hatchability performance. In conclusion, $0.50 \%$ MOS-supplemented diet might be used to obtain better production and reproduction of Japanese quail breeders.

\section{Acknowledgements}

We warmly acknowledged Avian Research and Training Centre, Department of Poultry Production, UVAS, Lahore, Pakistan for providing of birds and research facilities.

\section{Authors' Contributions}

MAl conducted research as part of his Ph.D. studies and drafted the manuscript. NR supervised the research work. OK helped in laboratory work. AH critically analyzed and interpreted results. MIA helped in preparation and drafting the manuscript. QAA reviewed the manuscript.

\section{Conflict of Interest Declaration}

All the authors declare that they have no conflict of interest for this work.

\section{References}

Abd El-Samee, D.L., El-Wardany, I., Ali, N.G. \& Abo-El-Azab, O.M., 2012. Egg Quality, Fertility and Hatchability of laying quails fed diets supplemented with Organic Zinc, Chromium Yeast or mannan-oligosaccharides. Int. J. Poult. Sci., 3, 221-224.

Akram M., Hussain, J., Ahmad S., Rehamn, A., Lohani, F., Munir, A., Amjad, R. \& Noshahi H., 2014. Comparative study on production performance, egg geometry, quality and hatching traits in four close-bred stocks of Japanese quail. Agri. Advan., 3, 13-18.

Anandh, M.A., Jagatheesan, P.R., Kumar, P.S., Paramasivam, A. \& Rajarajan, G., 2012. Effect of rearing systems on reproductive performance of Turkey. Vet. World, 5, 226-229.

Bonos, E., Christaki, E. \& Florou-Paneri, P., 2010. Performance and carcass characteristics of Japanese quail as affected by sex or mannanoligosaccharides and calcium propionate. S. Afr. J. Anim. Sci., 40, 173-184.

Considine, M., (2000). Altech report; Bio-Mos. 107.eng. RT.

Dankowiakowska, A., Kozłowska, I. \& Bednarczyk, M., 2013. Probiotics, Prebiotics and symbiotics in poultry mode of action, limitation, and achievements. J. Cent. Europ. Agr., 14, 467-478.

Dauda, G., Momoh, O.M., Dim, N.I. \& Ogah, D.M., 2014. Growth, production and reproductive performance of Japanese quails (Coturnix coturnix japonica) in humid environment. Egypt. Poult. Sci. J., 34, 381-395.

De Lange, L.L.M., Kocher, A. \& Beeks, W., (2007). Proceedings 27th Western Nutrition Conference. Alltech symposium, Lexington, Kentucky, USA.

de Paiva, J.B., Leite, J.L., da Silva, L.P.M., Rojas, T.C.G., de Pace, F., Conceição, R.A., Sperandio, V. \& da Silveira, W.D., (2015). Influence of the major nitrite transporter NirC on the virulence of a Swollen Head Syndrome avian pathogenic E. coli (APEC) strain. Vet. Microb., 175, 123-131.

Duncan, D.B., 1955. Multiple range and multiple F tests. Biometrics, 11: 1-42. 
Gibson, G.R., Probert, H.M., Van, loo J., Rastall, R.A. \& Roberfroid, M.B., 2004. Dietary modulation of the human colonic microbiota: updating the concept of prebiotics. Nut. Res. Rev., 17, 259-275.

Güçlü, B.K., 2011. Effects of probiotic and prebiotic (mannanoligosaccharide) supplementation on performance, egg quality and hatchability in quail breeders. Ank. Üni. Vet. Fak. Derg., 58, $27-32$.

Haidary, A.S., 2013. Productive and reproductive performance of four close-bred stocks of Japanese quail reared under different dietary levels of lysine. M.Phil Thesis, University of Veterinary and Animal Sciences, Lahore, Pakistan.

Hajati, H., Hassanabadi, A. \& Teimouri, Y.A., 2014. The effect of dietary supplementation of prebiotic and probiotic on performance, humoral immunity responses and egg hatchability in broiler breeders. Poult. Sci. J., 2, 1-13.

Halas, V. \& Nochta, I., 2012. Mannanoligosaccharides in nursery pig nutrition and their potential mode of action. Anim., 2, 261-274.

Hooge, D.M., 2003. Broiler chicken performance may improve with MOS. Feedstuffs, 6, 11-13.

Kocher, A., 2007. Effect of Mannan-oligosaccharides on broiler breeder performance. In: Proc. 19th Australian Poultry Science Symposium, Sydney, New South Wales, Australia, 173-176.

Lomax, A.R. \& Calder, P.C., 2009: Prebiotics, immune function, infection and inflammation: A review of the evidence. Brit. J. Nut., 101, 633-658.

Lopes, M., Roll, V.F.B., Leite, F.L., Dai Prá, M.A., Xavier, E.G., Heres, T. \& Valente, B.S., 2013. Quicklime treatment and stirring of different poultry litter substrates for reducing pathogenic bacteria counts. Poult. Sci., 92, 638-644.

Malago, J.J. \& Baitilwake, M.A., 2009. Egg traits, fertility, hatchability and chick survivability of Rhode Island Red, local and crossbred chickens. Tanz. Vet. J., 26, 24-34.

Rehman, A. \& Qaisrani, I.A., 2013. Comparative study on some hatching traits among four close-bred stocks of Japanese quail. Agri. Adv., 2, 288-291.

Rehman, H., Vahjen, W., Kohl-Parisini, A., ljaz, A. \& Zentek, J., 2009. Influence of fermentable carbohydrates on the intestinal bacteria and enteropathogens in broilers. World's Poult. Sci. J., 65, 75-89.

Roberfroid, M.B., 2007. Inulin-Type Fructans: Functional Food Ingredients. J. Nut., 137, 2493S-2502S.

Samanta, A.K., Jayapal, N., Senani, S., Kolte, A.P. \& Sridhar M., 2013. Prebiotic inulin: Useful dietary adjuncts to manipulate the livestock gut microflora. Braz. J. Microb., 44, 1-14.

SAS, (2002-03). SAS/STATE User's guide: Statistics Version 9.1. SAS Institute, Inc. Cary, North Carolina, USA.

Shashidhara, R. G. \& Devegowda G., 2003. Effect of dietary Mannan-oligosaccharides on broiler breeder production traits and immunity. Poult. Sci., 82, 1319-1325.

Spring P., Wenk C., Dawson K. A. \& Newman, K. E., 2000. Effect of Mannan-oligosaccharide on different cecal parameters and on cecal concentration of enteric bacteria in challenged broiler chickens. Poult. Sci., 79, 205-211.

Vahdatpour, T., Nikpiran, H., Moshaveri, A., Ahmadzadeh, A., Riyazi, S.R. \& Vahdatpour, S., 2011. Effects of active, inactive and compounded Saccharomyces cerevisiae on growth related hormones and performance of Japanese quails (Coturnix Japonica). Afr. J. Biotech., 10, 15205-15211.

Verdonk, J.M., Shim, S.B., Van Leeuwen, P. \& Verstegen, M.W., 2005. Application of inulin-type fructans in animal feed and pet food. Brit. J. Nut., 93,S125-38.

Yang, Y., lji, P.A., Kocher, A., Mikkelsen, L.L. \& Choct, M., 2008. Effects of Mannan-oligosaccharide and fructooligosaccharide on the response of broilers to pathogenic Escherichia coli challenge. Brit. Poult. Sci., 49, 550559. 